\title{
Bir Gerilla Pazarlama Uygulaması Olarak Ambient Reklamcılık (Ortam Reklamcılığı): Basılı Dergi Reklamı ile Ambient Reklamın Etkililik Açısından Karşılaştırılması*
}

\author{
Ambient Advertising as a Guerrilla Marketing Practice: The Comparison of Traditio- \\ nal Printed Ads and Ambient Advertising in Terms of Effectiveness
}

\section{Prof. Dr. Mine Oyman - Serhat Özer}

Başvuru Tarihi: 26.07.2017

Kabul Tarihi: 29.09.2018

\section{Öz}

Günümüz pazar şartları ve değişen tüketici profili markaları farklı iletişim teknikleri kullanmaya zorlamaktadır. Uygulamada sıklikla karşılaşılan bu farklı yöntemlerden bir tanesi gerilla pazarlamadir. Gerilla pazarlama, temel felsefesi bağlaminda geleneksel olmayan, düşük maliyetli, şaşırtıcı, yaratıcı, kışkırtıcı ve sıra dışı pazarlama faaliyetlerini kapsayan şemsiye bir terimdir. Gerilla pazarlamanın en sık karşılaşılan uygulamalarından birisi ambient reklamciliktır. Ambient reklamcilik, reklam mesajlarinin iletilmesi amaciyla tüketicilerin etkileşim içerisinde oldukları çevresel elemanları kullanan ve bu elemanları reklamcılık açısından anlaml hale getiren gerilla reklamcilı formudur. Bu çalışmada nicel bir yöntem araciliğlyla bir dergide uygulanan geleneksel reklam ile ambient reklamin etkililik açısından bir karşılaştırılması yapılmış ve tüketicilerin bu reklamlara yönelik tutumlar reklamlara yönelik genel inanç değişkeni açısından incelenmiştir. Bu bağlamda genel tarama modeli ile 388 üniversite öğrencisinden anket araciliğıyla veri toplanmıştır. Genel bir sonuç olarak ambient reklamin geleneksel basil reklamlardan algılanan sürpriz etkisi ve reklama karşı tutum değişkenleri açısından daha etkili olduğu tespit edilmiştir.

Anahtar Kelimeler: Gerilla Pazarlama, Ambient Reklamcilik, Reklamda Etkililik

\begin{abstract}
Today's market conditions and changing customer profile force brands to use different communication techniques. One of the different techniques which is frequently seen in practice is guerrilla marketing. Guerrilla marketing, in the context of its main philosophy, is an umbrella term which comprises untraditional, low cost, surprising, creative, provocative and uncommon marketing activities. The most encountered form of guerrilla marketing is ambient advertising. Ambient advertising is a form of guerrilla advertising which uses environmental elements that consumers interact with and makes these elements meaningful in terms of advertising for the aim of conveying advertising messages. In this study, a comparison in terms of advertising effectiveness between traditional printed magazine ads and ambient advertising was made through a quantitative study. Consumers' attitudes towards these advertisements were investigated in terms of general belief towards these two types of advertisements. In this context, the data were collected from 388 university students through general surveying with a questionnaire. Overall results indicate that ambient advertising is more effective than traditional printed ads in terms of perceived surprise effect and attitude towards advertising.
\end{abstract}

Keywords: Guerrilla Marketing, Ambient Advertising, Advertising Effectiveness

Prof. Dr. Mine Oyman, Anadolu Üniversitesi İşletme Fakültesi, moyman@anadolu.edu.tr

Serhat Özer, Anadolu Üniversitesi Pazarlama Programı Doktora Öğrencisi, serhatozer@hotmail.com

* Bu çalışma Serhat Özer'in Anadolu Üniversitesi SBE Pazarlama Programı́da hazırladığı YL tezinden türetilmiştir. 


\section{Giriş}

Gelişen pazar şartları günümüzde rekabeti çok üst seviyelere taşımıştır. Bu zorlu rekabet ortamında işletmeler ürün ve hizmetleriyle ilgili en etkili iletişim karmasını belirlemeye çalışmaktadır. Tüketicilerle doğrudan iletişim sağlamak adına en sık uygulanan iletişim faaliyeti ise reklamlardır. Bu sebeple tüketiciler gün içerisinde binlerce reklam mesajına maruz kalır ve bu reklamları zihinlerinde oluşan reklam şeması (Bartlett, 1932; Dahlen ve Edenius, 2007'den aktaran Jurca ve Madlberger, 2015, s. 52) içerisine yerleştirir. Tüketiciler bu reklamlardan bazılarının artık hiç çekici gelmediğini, aksine itici gelmeye başladığını düşünebilmektedir çünkü tüketicilerin zihni geleneksel formda uygulanmış binlerce reklama ev sahipliği yapmaktadır. Bu durumda seçici algı söz konusu olmaktadır. İnsanlar sşı, renk, ses, koku gibi temel uyarıcılara duyusal alıcıları aracılığıyla ani tepkiler verebilmektedir. Algı bu sistem aracılığıyla insanların uyarıcıları seçmesi, organize etmesi ve yorumlaması süreci olarak tanımlanabilir (Solomon, 2013, s. 70). Tüketiciler bir uyarıcıya maruz kaldıkları zaman bilinçsiz bir şekilde seçici olurlar ve maruz kaldıkları uyarıcıların çok küçük bir bölümünü algılarlar. Genel olarak hangi uyarıcının algılanacağı ise uyarıcının kendi doğasına ek olarak tüketicinin beklentilerini etkileyen geçmiş deneyimleri ve sahip olduğu güdüler (ihtiyaç, istek ve arzular) tarafindan belirlenir. Yani tüketicilerin beklentileri, deneyimleri ve güdüleri ile paralel olan girdileri (uyarıcıları) algı sürecine dahil edip, maruz kaldıkları diğer uyarıcıları algılama süreçlerinin dışında bıraktıkları söylenebilir. Bu faktörlerin her biri uyarıcının algılanabilme olas1lığını arttırır ya da azaltır (Odabaşı ve Barış, 2002, s. 128; Schiffman ve Wisenblit, 2015, s. 122). Bu bağlamda düşünüldügünde günümüz tüketicisinin reklamlarda yaratıcı, farklı, dikkat çekici, şaşırtıcı hatta biraz da kışkırtıcı unsurları bekledikleri söylenebilir. Tüketicinin iletişim faaliyetini olumlu yönde algılayıp ürün ya da hizmete yönelik istenilen davranış ya da tutumu sergilemesinde bir diğer önemli faktör de yapılan iletişim faaliyetinin reklam olarak algılanmaması diğer bir deyişle organik olarak algılanmasıdır. $\mathrm{Bu}$ durumun gerçekleşebilmesi geleneksel mecralar üzerinde çok zordur. Bu sebeple gerilla pazarlama faaliyetleri ve özellikle onun uygulama alanlarından birisi olan ambient (ortam) reklamcillk kavramı günümüz reklamcılık teknikleri açısından çok önemli bir yere sahiptir.

\section{Gerilla Pazarlama ve Uygulamaları}

Gerilla pazarlama kavramı yazında birçok açıdan incelenmiş bir kavramdır. Genel olarak gerilla pazarlama ile ilgili yazın; konunun kapsamı, araçları, pazarlama iletişimindeki yeri ve etik boyutu gibi kavramsal olarak ele alan çalışmalar (Hutter ve Hoffmann, 2011; Bigat, 2012; Nardalı, 2009; Ay vd., 2010; Çeltek ve Bozdoğan, 2012); spor, hizmet sektörü ve KOBİ'ler gibi alana yönelik çalışmalar (Ay ve Ünal, 2002; Baltes ve Leibing, 2008; Ünal, 2013; Navratilova ve Milichovsky, 2015) ve satın alma niyeti, marka değeri, marka farkındalığı üzerindeki etkisi gibi etki açısından irdeleyen çalışmalar olarak üç genel alt grupta siniflandırılabilir (Prevot, 2009; Mughari, 2011; Tam ve Khuong, 2015).

Gerilla pazarlama 1980'li yılların başlarında Jay Conrad Levinson tarafindan pazarlama yazınında detaylı bir şekilde irdelenmiş ve hayat bulmuş bir kavramdır. Bu kavramın başka yazarlar tarafından benzer şekilde kullanılmış olmasına rağmen fikir babasının Levinson olduğu söylenebilir. Geleneksel pazarlama anlayışından farklı bir yaklaşımla pazarlamanın yürütülmesi gerekliliğini öne süren bu yaklaşımda temel amaç ve çıkış noktası, küçük ve orta ölçekli işletmelerin kendilerinden daha büyük şirketlerle rekabet edebilmelerinde sıra dışı, yaratıcı, hayal gücü gerektiren ve bazen maliyetsiz bazense çok düşük maliyetlerle çok büyük etkiler yaratabilecek pazarlama iletişimi faaliyetlerini gerçekleştirmek, sürdürmek, korumak ve bu sayede "kârllı̆ğa" ulaşmaktır. Gerilla pazarlama çabuk hareket gerektirir, hayal gücü ve yaratıcılıktan faydalanır. Ayrıca küçük ve orta ölçekli işletmelerin rakiplerini küçük, periyodik ve şaşırtıcı ataklarla demoralize etmelerine olanak sağlar (Tek, 1999'dan aktaran Ay vd., 2010, s. 281). Levinson pazarlama ile ilgili yapılan tüm yaratıcı ve göz alıcı reklamların gerilla pazarlama kavramına ait olduğunu iddia etmiştir. Bu sebeple gerilla pazarlama siradan olmayan, değişik, orijinal, kışkırtıcı, esnek, dinamik, yenilikçi ve yaratıcı uygulamalar olarak tanımlanabilir (Hutter ve Hoffmann, 2011, s. 41). Gerilla pazarlama geleneksel pazarlamaya oranla kısmen daha az maliyetle sürpriz ve yayılma etkisini ortaya çıararak çok fazla alıcının reklam mesajına dikkatinin çekilmesini amaçlayan geleneksel olmayan reklam kampanyalarını kapsayıcı bir terimdir (Hutter ve Hoffmann, 2011, s. 42). 
Özgül (2008, .s 190) pazar koşullarında gerilla pazarlama stratejisinin kullanılma nedenleri olarak iletişim kirliliği, bilgi bombardımanı, medyanın çeşitlenmesi, medyada yer almanın artan maliyeti, azalan yaratıc1lık, reklamın inandırıcılığını yitirmesi, niş pazarların önem kazanması ve niş medyanın ortaya çıkması faktörlerini göstermiştir.

Gerilla pazarlama yöntemleri reklam kampanyalarının stratejik etkisini ve verimliliğini arttırabilmektedir. Bu taktikler genellikle alışıldık, çizgi üstü medyayla yan yana yer alabilecek ve entegre bir kampanyanın parçası olarak bu medya tipini destekleyecek bir biçimde yaratılır (Burtenshaw vd., 2014, s. 52). Levinson'a göre gerilla pazarlama uygulamaları minimedya ve maksi-medya planlaması olarak iki başlık altında toplanabilir (Levinson, 1998'den aktaran Dahan ve Levi, 2012, s. 40). Mini-medya planlamasinda kitle iletişim araçları kullanılmaz ve işletmenin komisyon ödemeden yaptığ gerilla pazarlama çalışmaları bulunur, maksi-medya planlamasinda ise kitle iletişim araçları ile yapılan diğer uygulamalar bulunmaktadır (Dahan ve Levi, 2012, s. 40). Gerilla pazarlama geleneksel olmayan birçok sıra dışı pazarlama faaliyetini kapsar. Bu sebeple gerilla pazarlama şemsiye bir kavramdır. Bu yöntemlerin her biri kendi içerisinde gerilla pazarlamanın spesifik özelliklerinden bazılarını barındırır. Uygulamada sıklıkla karşılaşılan gerilla pazarlama aktiviteleri ise viral pazarlama, gizli pazarlama (stealth marketing), sinsi pazarlama (ambush marketing), deneyimsel pazarlama (experiential marketing), gerçek zamanlı pazarlama (real-time marketing) ve ortam pazarlaması ve reklamcilığıdır (ambient marketing).

$\mathrm{Bu}$ çalışmada gerilla pazarlama faaliyetlerinden birisi olan ambient reklamcllık incelenmiştir. Bu çalışma alanının seçilme nedeni ambient reklamların uygulamada en sık karşılaşılan gerilla pazarlama faaliyetlerinden biri olması ve Avrupa, Asya ve Amerika'da 6,11 milyar dolara ulaşan (Honomichl, 2013'den aktaran Wu vd., 2016, s. 150) bir reklam endüstrisi haline gelerek gelişme kaydetmesidir.

\section{Ambient Kavramı ve Ambient Reklamcilık}

Ortam pazarlaması yazında "ambient" kavramı altında farklı terimlerle (medya, iletişim, pazarlama, reklamcılık) isimlendirilse de yapılan çalışmalarda genel olarak ele alınan bir reklam çalışması olmuştur. Temel olarak ambient reklamcılık, tüketicilerin günlük yaşamlarında sıklıkla etkileşim içerisinde oldukları çevreye ait elemanların sıra dışı, yaratıcı, tüketicinin beklemediği bir biçimde ve değişime uğratılarak marka mesajının iletilmesi amaciyla kullanılması faaliyetidir. Ortam reklamcılığına açıkhava reklamcılığının gerilla formu da denilmektedir (Hutter ve Hoffmann, 2011, s. 43). Luxton ve Drummond (2000, s. 735) "sıradışı ve beklenmeyen konumlara, geleneksel olmayan yöntemlerle, özgün bir şekilde bunu gerçekleştiren ilk reklam uygulaması olarak reklamların yerleştirilmesi”ni ambient reklamcılık olarak tanımlamaktadır. Ambient reklamcılığın artan popülaritesine rağmen, terim açık bir kavramsallaştırma eksikliği yaşamaktadır. Deneyimsel reklamcılık, kaldırım reklamcılığı, sokak reklamcılığı, transit reklamcilık ve ambient reklamcllık gibi kavramlar genellikle birbirinin yerine kullanılabilen kavramlardır. Bu kavramlar aynı kavramsal çerçevenin içerisinde iç içe girmiş gibi görünmektedir. Bu kavramsal çerçeve açıkhava reklamcilı̆̆ıdır (Lichtenthala vd., 2006'dan aktaran Karimova, 2014, s. 252). Ambient kavramı ile ilgili yazın tarandığında karşımıza ambient medya, ambient reklamcilık, ambient pazarlama ve ambient iletişim gibi terimler çıkmaktadır. Ambient kavramı reklamla ilgili olarak ilk defa açık hava reklam kampanyalarında uzmanlaşmış olan İngiltere merkezli Concord Reklamcılık tarafından 1996 yılında kullanılmıştır. $\mathrm{Bu}$ ajansın müşterilerinin ajanstan sürekli "daha farklı bir şey" isteme ricalarına yönelik olarak ambient terimi ortaya çıkmıştır. Rekabet, azalan etkinlik ve ilgisini yitirmiş kitlelerle ilgili sorunları olan şirketler ajanslarından bu şekilde reklamlar istemişlerdir. Müşterilerin farklı bir şey isteme ile ilgili zorlamaları sonucu reklamlar zemin, petrol pompaları ve tuvalet kapılarının arkaları gibi daha önce reklam alanı olarak düşünülmeyen yerlere yerleştirilmeye başlanmıştır. Bu şekilde yürütülen kampanyalar açık hava, basilı medya, televizyon ve radyo gibi var olan mecra kategorilerine uygun olmadığından dolayı yeni bir terim olan "ambient" (ortam) terimi yazına kazand1rilmıştır (Luxton ve Drummond, 2000, s. 735).

Yazında ilk başlarda, özellikle 1990'lı yıllarda kullanılan terim "ambient medya" (Simmons, 1995'; Cook

1 http://www.campaignlive.co.uk/article/53874/media-mediachoice-ambient-media\# (Erişim Tarihi: 01.06.2016) 
ve Woolgar, 19962; Bainbridge ve Curtis, 19983; Shankar ve Horton, 1999; Burtenshaw vd., 2014) iken, daha sonraları "ambient reklamcillk" (Luxton ve Drummond, 2000; Reyburn, 2010; Chatterjee, 2011; Jurca, 2012; Jurca ve Ioan, 2013; Maniu ve Zaharie, 2014), "ambient iletişim" (Gambetti, 2010; Graffigna vd., 2011; Biraghi vd., 2015; Rosengren vd., 2015) ve "ambient pazarlama" (Başev, 2015; Bargenda, 2015) ve "sokak pazarlaması" (Saucet ve Cova, 2015) kavramı altında da ambient kavramı incelenmiştir.

Ambient, medya olarak ele alındığında "geleneksel olmayan dış mekân" medyası olarak görülür (Shankar ve Horton 1999, s. 2). Bu tanıma göre ambient kavramı geleneksel olmayan biçimde kullanılan bir açık hava mecrasıdır. Jurca'ya (2012, s. 212) göre ambient reklamcılık kavramı yazında yeni bir kavramdır ve bu yüzden kavram üzerinde yoğun bir bulanıklık söz konusudur. Kavramı kapsayan belirsizlik, kavramın yeni oluşundan (Luxton ve Drummond, 2000, s. 735) olduğu kadar ambient formunun sürekli evriminden de kaynaklanmaktadır (Jurca, 2012, s. 212). Maria ve Ioan (2013, s. 1765) ambient reklamcilı̆̆1, doğrudan ve bağlamsal mesajları, varolan çevre elemanlarını hedef kitleyi şaşırtacak şekilde kullanarak ve sıklıkla değiştirerek ileten yaratıcı formda diş mekân reklamcilığı olarak tanımlamıştır. Gambetti (2010, s. 34) ambient iletişimi, tüketici bağlılığını ortaya çıkaran mesajların iletilmesinde mümkün olan her türlü fiziksel yüzeyi kapsayarak çevre elamanlarını kullanan kurumsal iletişimin kompleks bir türü olarak tanımlamakta, genel olarak geleneksel medyadan daha az pahalı ve daha düşük maliyetli bir şekilde kentsel çevreyi kullanmasına dikkati çekmektedir. Ambient iletişim özellikle dünya genelinde yaşanan ekonomik kriz dönemlerinde önemli bir şekilde pazarlama destekleyicisi bir medya haline gelmiştir. Gambetti’nin tanımı geniş ve kapsayıcıdır çünkü marka mesajlarının iletilmesinde kullanılabilecek iç ve dış (indoor-outdoor) alanları kapsar (Rosengren vd., 2015, s. 22). Ambient iletişim son zamanlarda yeniden doğan köklü bir reklamcılık formudur ve Avrupa'da açıkhava reklamcılığının ilk formlarına kadar uzanır. On ikinci yüzyılın ikinci yarısında sokaklarda kraliyet ve hükümet duyurularını yapan kişiler, onbeşinci yüz-

2 http://www.campaignlive.co.uk/article/51034/ambient-media-ambient-media (Erişim Tarihi:01.06.2016)

3 http://www.campaignlive.co.uk/article/59016/ambient-media-ambient-trail- (Erişim Tarihi: 01.06.2016) yılın ikinci yarısında promosyonel el ilanları ve onyedinci yüzyılın sonlarındaki reklam posterleri açıkhava reklamcilığının ilk örnekleri olarak gösterilebilir (Brioschi, 1984'den aktaran Biraghi vd., 2015, s. 7).

Ambient pazarlama kavramı ise, dikkat çekmeyi ve tüketicinin tahmin etmeyeceği, özellikle geçmişte bir reklamın görülmediği ortamlarda yer almayı hedefleyen kampanya türüdür (Bainbridge ve Curtis 1998'den aktaran Başev, 2015, s. 271). Hutter ve Hoffmann da (2011, s. 43) ambient pazarlamayı tüketicilerin reklam mesajı görmeyi beklemedikleri bölgelere reklamların yerleştirilmesiyle açı bir şekilde tüketiciyi şaşırtma faaliyeti olarak tanımlamıştır.

Tüm bu kavramlar dikkatli bir şekilde incelendiğinde hiçbirinin diğerini dışlamadığ 1 aksine birbirleriyle iç içe olan kavramlar oldukları görülmektedir. Sonuç olarak bugün ambient kavramı, hedef kitleye ulaştırılması gereken marka mesajının, bütçe limitleri içerisinde yaratıcı bir şekilde, uyumlu olabilecek doğru lokasyonun bulunması ile ilgilidir. Bu sebeple "ambient reklamcllık" terimi kavramın tam olarak anlaşılmasında en kapsamlı terimdir (Jurca, 2012, s. 215). Tüm bu tanımlar ışı̆̆ında genel ve kapsamlı bir ambient reklamcilık tanımına ulaşılabilir. Bir reklam mesajının, tüketicilerin günlük hayatlarında sıklıkla etkileşim içerisinde oldukları çevreye (outdoor ve indoor/açı ya da kapalı alana) ait, üzerinde bir marka mesajı beklemedikleri elemanlar aracılı̆̆ıyla, yaratıcı, sıra dışı ve geleneksel olmayan formda, mesaj içeriğgi ve mecra uyumunun sağlandığı bir şekilde iletilmesi faaliyetine "geleneksel olmayan ortam-bazh reklamcılık" (ambient) denilmektedir. Ambient reklamlar kısa vadede yaratıcı ve sürpriz etkisiyle tüketiciyi şaşırtma; uzun vadede ise sıra dişı oluşuyla kendisini geleneksel reklamlardan ayırma ve akılda kalıcı olma etkisine sahiptir. Bu özellikleri ile ambient reklamlar doğru uygulandığında reklamdan istenilen etkinliği sağlayabilmesi açısından önemli bir araç olarak karşımıza çıkmaktadır.

\section{Ambient Reklamcılığın Gelişme Nedenleri}

Chatterjee (2011, s. 87) ambient reklamların yükselişine sebep olan faktörleri reklamveren açısından pazarda kısa dönemli hedeflere odaklanma, mali kaygıların artması, geleneksel medyanın etkinliğindeki 
düşüş, pazardaki marka sayısındaki artış, markaların yeni iletişim kanalları bulma çabası ve ambient medyanın daha iyi bir hedefleme sunması olarak belirtmiştir.

Günümüz dünyasında reklamlar tüketicileri farkında olmadıkları yollarla etkileyerek onların günlük yaşamlarının bir parçası haline gelmiştir. Tüketiciler evlerinin dişında olsun ya da olmasın reklamlar her adımlarında onları çevrelemektedir. Televizyon, radyo, İnternet, açıkhava ilan panoları ve tüm medya kanalları tüketicileri satın almaya niyetli hale getirebilmek için onlara ticari mesajlar göndermeye çalışmaktadır. Bununla birlikte, insan beyni tüm bu mesajları aynı etkinlikte işleyemez. Beynin alakasız görünen bilgiden kaçınması eğiliminin yanı sıra, günümüzde tüketiciler kendilerini ticari mesajlara neredeyse duyarsız hale getiren bir "reklam körlügü" geliştirme eğilimindedirler (Reyburn, 2010'dan aktaran Jurca, 2012, s. 210).

"Geçen yıllar içerisinde televizyon, radyo, İnternet ya da ilan panoları gibi geleneksel reklam medyası marka mesajlarının etkin olarak iletilmesi açısından yeteneklerini kaybetmişlerdir. Bunun temel sebebi "reklam karmaşası" denilen fenomendir"(Rosengren, 2008, s. 27). "Reklam karmaşası terimi genellikle çok sayıda tüketiciyi kapsayan yüksek sayıdaki pazarlama mesajlarını anlatmak için kullanılır” (Rosengren, 2008, s. 28). "Tüketicinin algıladığı reklam karmaşası belirli bir medya üzerinde aşırı miktarda reklamın olduğu inancıdır" (Eliot ve Speck, 1997'den aktaran Jurca, 2012, s. 211). "Bunun temel sonucu tüketicilerin reklamdan kaçınmalarının artışıdır, bu durum da neticede reklam mesajının etkisizliğine sebep olur. Bu bağlamda ambient reklamcılık stratejisi daha cazip olmaya başlamıştır çünkü ambient reklamcilık stratejisi tüketicinin zihninde kalıcı bir marka imajı yaratarak reklam karmaşasından bir çıkış yolu önerebilmektedir" (Jurca, 2012, s. 211).

\section{Reklamın Etkililiği ve Ambient Reklamın Özellikleri}

Reklamda etkililik bir reklamın amaçlarına ne kadar ulaştı̆ğ ile belirlenir ve genel olarak reklama yönelik pazar tepkisi (satı̧ hacmi, pazar payı vb.) ve reklamın yarattığ ${ }_{1}$ iletişim etkililiği (farkındalık, tercih etme, müşteri memnuniyeti ve sadakati) gibi iki farklı çerçevede ölçümlenebilir. Reklam iletişim etkililiğinin ölçümünde bilişsel tepki modelleri ve duygusal tepki modelleri kullanılır (Vakratsas ve Ambler, 1999'dan aktaran Alnıaçı vd., 2010, s. 89; Mc Alister vd., 2006 'dan aktaran Hamelin vd., 2017, s. 103). Reklam etkililiğinin bilişsel boyutu düşünme ve zihinsel aktivite aracilığıyla bilginin işlenmesi anlamına gelir ve yardımsız ve yardımlı hatırlama ve farkındalıkla ölçülür. Reklam etkililiğinin duygusal boyutu ise tüketicinin reklama yönelik duygu bazlı tutumlarını ve içsel hislerini temsil eder (Aaker, 1991; Barry ve Howard, 1990'dan aktaran Zenetti ve Klapper, 2016, s. 353).

Bu çalışmada ise MacKenzie, Lutz ve Belch'in (1986, s. 131) "reklama yönelik tutum modeli" üzerinden geleneksel dergi reklamları ve ambient reklamın etkililiği incelenmiştir. Bu model tüketicilerin reklamlara yönelik verebilecekleri tepkilerinin bilişsel (dikkat gibi), duygusal (reklama ve markaya yönelik tutum gibi) ve çaba ile ilgili (satın alma niyeti gibi) boyutlar üzerinden olabileceğini önermektedir. Ambient reklamların sıradışı olması ve beklenmeyen yerlerde uygulanması tüketicilerin dikkatlerini çekmektedir ve tüketiciler bu duruma yönelik bilişsel bir açıklama bulmaya çalışmaktadır. Bilişsel psikoloji alıcının dikkatinin bir mesajın işlenmesinde ön koşul olduğunu önermektedir. Bununla birlikte sürpriz etkisine sahip bir uyarıcı (ambient reklam) duygularla ilgili tepkileri de güçlendirebilmektedir. Bu sebeple ambient reklamların da reklama ve markaya yönelik tutum gibi duygusal değerlendirmeleri güçlendirmesi beklenmektedir. Bu duygusal değerlendirmeler de çabaya yönelik tepkileri yansıtarak satın alma niyetine öncülük etmektedir. Bu nedenle çalışma kapsamında reklam etkililiğinin ölçümünde bilişsel, duygusal ve çabaya yönelik boyutlar üzerinden bir inceleme yapılmıştır (Anderson, 2005; Brown ve Stayman, 1992'den aktaran Hutter, 2015, s. 37).

Jurca ve Madlberger (2015, s. 51) reklamin etkililiğinin tüketiciye iletilen reklam mesajını tüketicinin ne seviyede işlediğine bağlı olduğunu savunmaktadır. Tüketicilerin zaman içerisinde işleme aldıkları ve algıladıkları bilginin zihinde birikmesi ve organize edilmesi zihin içerisinde bir "şema"nın oluşmasını sağlar. Bu sayede yaşanılan her yeni deneyim şemanın aktif hale gelmesine ve geçmişteki bilgilerle zihnin ilişki kurmasına neden olur. Reklamlarda ileti- 
len marka mesajları da tüketicilerin işleme almaları gereken bilgilerdir. Bu sebeple şema teorisine dayanarak tüketicilerin reklamlarda aktarılan marka mesajları üzerinde bilgiyi işleyerek bir "reklam şeması" geliştirdikleri söylenebilir (Bartlett, 1932; Dahlen ve Edenius, 2007'den aktaran Jurca ve Madlberger, 2015, s. 52). Reklam şeması, tüketicinin herhangi bir reklamdaki marka mesajıyla karşılaştığında algılamasını ve bilgiyi işleme sürecini kolaylaştırır. Jurca ve Madlberger (2015, s. 53) ambient reklamların tüketicilerin zihinlerinde geleneksel reklamlarla ilgili yarattıkları şema ile bir uyumsuzluk yaratacağını fakat bu uyumsuzluğun reklamın etkililiğe ulaşmasında önemli bir belirleyici olacağını belirtmektedir. Bu duruma ise "şema uyumsuzluğu" denilmektedir. Bu uyumsuzluğa sebep olan ambient reklam özellikleri Jurca ve Madlberger (2015, s. 53) tarafindan yaratıcıllk, beklenmezlik/beklenmedik olma (sürpriz), katılım ve zeka olarak belirtilmiştir.

Reklamda yaratıcılık, tüketicilerin geliştirmiş oldukları geleneksel reklamlardan kaçınma davranışının üstesinden gelinmesinde en temel şarttır. "Yaratıcılık kullanılan medyaya bağlı olarak reklam mesajının iletilmesinde farklı bir yolla reklama yardımcı olur. Yaratıcı olsun ya da olmasın geleneksel reklamlar tüketiciler için çok bilindik ve hatta sıkıcı hale gelebilmektedir" (Maniu ve Zaharie, 2014a, s. 1165). Dahlen vd.ne göre (2008, s. 402) "yaratıc1 reklamc1lık yeni bir mesajın iletilmesi ile değil, aynı mesajın farklı bir yolla iletilmesi sayesinde tüketicinin markaya olan ilgisini arttırır." Ambient reklamlarda mesaj geleneksel olmayan çok farklı yollarla tüketiciye ulaştırılır. Bu yaratıcılık tüketicinin reklam mesajına ve dolayısıyla markaya olan ilgisini arttırır. "Reklamın yaratıcı olmasında orijinallik ve reklamın uyumluluğu yaratıcılığın iki önemli boyutu olarak düşünülür. Reklam geleneksel olmayan bir bağlamda uygulandığında hem orijinallik hem de reklamın uyumu tüketiciler tarafından yüksek olarak algılanır ve reklamın daha yaratıcı olduğu düşünülür” (Maniu ve Zaharie, 2014b, s. 46).

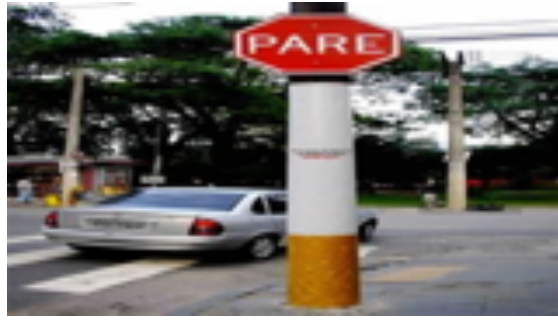

Şekil 1. Sigara Karşıtı Ambient Reklam ${ }^{4}$

Ambient reklamlar reklamın etkinliğe ulaşması açısindan tüketicilerin zihinlerinde önemli bir etken olan şema uyumsuzluğunu (Jurca ve Madlberger, 2015, s. 48) yaratır. "Yaratıcılık gibi beklenmezlik de uyumsuzlukların yorumlanması aşamasında tüketicinin ilgisini uyarır" (Yoon, 2013, s. 372). Luxton ve Drummond (2000, s. 735) ambient reklamları tanımlarken "sıradışı ve beklenmeyen konumlara, geleneksel olmayan metodlarla, ilk kez ya da bunu gerçekleștiren ilk reklam uygulaması olarak reklamların yerleştirilmesi” ifadesini kullanmıştır. Ayrıca beklenmeyen konumlar tüketiciler üzerinde "sürpriz etkisi" yaratarak reklama olan ilgi seviyesini arttırmaktadır. "Ambient reklamların beklenmezliği, tutundurma mesajının taşıyıcısı olarak spesifik bir medyanın tüketicilere olan yabancılı̆̆ından kaynaklanır" (Jurca ve Madlberger, 2015, s. 55). Ambient reklamlar sıklıkla var olan çevre elemanlarını hedef kitleyi şaşırtan bir yolla kullanır" (Jurca, 2012, s. 217) ve geleneksel reklam tiplerine aşırı maruz kalan tüketicilerin dikkatlerini çekmek amacıyla sürpriz etkisi yaratır (Hutter ve Hoffmann, 2013, s. 93). Eğer tüketiciler dikkatlerini reklama yönlendirirse, geleneksel bir reklam sadece bağlam (mesaj yazısı ya da görsel elemanlar beklenmeyen formda ya da uyumsuzsa) içerisinde sürpriz etkisi yaratır fakat ambient medya o ortamda bulunan tüketicileri etkilemek ve sürpriz etkisi yaratmak için çevrede bir farklılık yaratacak olan medyanın uyumsuz elemanlarını kullanır (Hutter ve Hoffmann, 2013, s. 94). Ambient reklamlarda bireylerin daha

4 https://tr.pinterest.com/pin/523121312936348957/ (Erişim Tarihi: 25.06.2016) 
önce görmedikleri bir uyarıcıyla ya da çevresel elemanların beklenmeyen kombinasyonlarını içeren bir uyarıcıyla karşılaştırılması ile sürpriz etkisi yaratılmış olur (Hutter, 2015, s. 35).

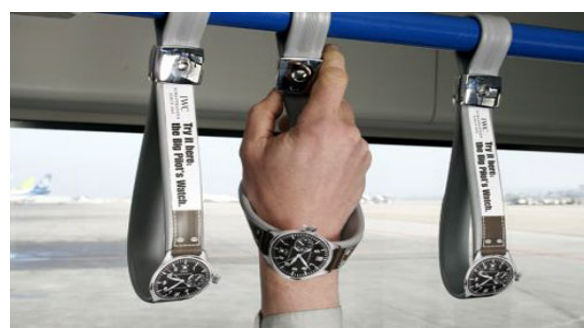

Şekil 2. IWC Saat Reklamı

Ambient reklamlar hedef kitle ile farklı derecelerde katılım ya da etkileşim oluşmasına olanak sağlar. Bu reklamlardaki fiziksel tüketici ve reklam etkileşimi, üzerinde sadece bir reklam mesajı olan yol üzerinde yürüyen tüketici etkileşimi gibi pasif formdaki etkileşimlerden ayrılmaktadır (Lee Yuen ve Dacko 2011'den aktaran Jurca ve Madlberger, 2015, s. 55). Katılım markaya karşı pozitif bir tutumun yaratılmasında yükselen bir rol oynamaktadır ve marka sadakati yaratımı için de önemli bir faktördür (Gambetti ve Graffigna, 2010; Brodie vd., 2013'den aktaran Jurca ve Madlberger, 2015, s. 55). "Gerilla reklamcllk gibi geleneksel olmayan ambient iletişim, sürpriz, şaşkınlık ve yenilik (orijinallik) gibi faktörler aracılığıyla tüketici katılımını ortaya çıkarmayı amaçlar" (Gambetti, 2010, s. 39).

Ambient reklamlar genellikle reklamı yapılan ürün ya da marka ile ilgili, önemli bir ya da birkaç özelliği ortaya çıkaran ve merak uyandıran reklamlardır. Genel amaç doğrultusunda çok fazla detaylı bilgi verilmesinden kaçınan bu reklamlar, aktarılmak istenen bilgi ile ilgili eksik bırakılan parçaların tüketiciler tarafından tamamlanmasını bekler. Ambient reklamların zekası, çevrede var olan elemanların kullanımı, düzenlenmesi ve bu elemanları mesajın iletilmesine dahil ederek bilginin eksik sunulmasından çok daha öteye gitmektedir (Jurca, 2012, s. 217). "Bir ambient reklamın başarılı olabilmesi için mesajın sadece tüketiciye uygunluğu yeterli değildir, mesaj aynı zamanda tüketicinin karşılaştığ 1 çevresel elemana yani reklam

5 https://tr.pinterest.com/pin/84442561734522628/ (Erişim Tarihi: 25.06 .2016 ) amacıyla kullanılan ya da değişime uğratılan ambient medyaya da uyumlu olmalıdır. Yani kullanılan mecra ile reklam mesajı arasında bir uyum olmalıdır. $\mathrm{Bu}$ uygunluk ne kadar güçlüyse, tüketicinin reklamı farketme, hatırlama ve ona cevap verme ihtimali de o kadar yüksek olacaktır" (Reyburn, 2010, s. 10). Bu şekilde daha önceden reklam açısından anlamsız olan bir nesne değişime uğratılarak ve uygun bir reklam içeriğinin uygulanmasıyla reklam açısından anlamlı hale getirilir. Bazı durumlarda reklam içeriği doğrudan reklam amacıyla değişime uğratılan nesnenin (medya) kendisidir. Bu durumda reklam daha farklı bir anlam kazanır. Bunun olabilmesi için marka ve medya arasında bir eşleşme olmalıdır. Uyumlu ve yaratıcı bir medya seçimi marka çağrışımını ve marka ve reklam değerlendirmesini güçlendirir. Fakat reklam içeriği ile uyumsuz olan yaratıcı bir medyanın seçimi bu etkiyi yaratamaz (Dahlen, 2005, s.95).

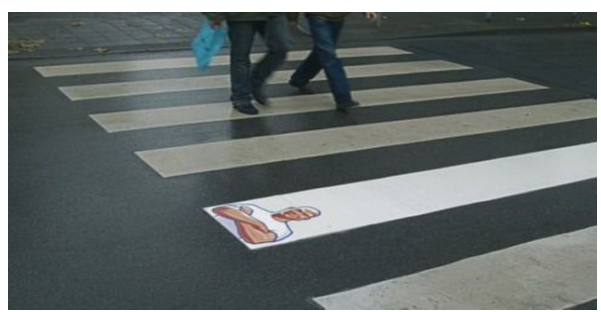

Şekil 3. Mr. Muscle Zemin Reklamı

\section{Araştırmanın Amacı ve Önemi}

$\mathrm{Bu}$ çalışmada geleneksel basılı dergi reklamları ve ambient reklam (ortam reklamı) arasında etkililik açısından bir farkın var olup olmadığı ortaya konulmaya çalışılmış ve tüketicilerin bu reklamlara yönelik tutumları, bu tutumların cinsiyet ve reklamlara yönelik genel inanç değişkeni açısından farklılaşıp farklılaşmadığı belirlenmeye çalışılmıştır.

Ambient reklamlar ülkemizde henüz çok yaygınlaşmamış reklamlardır. Ayrıca ambient reklamlar alanında yapılan sınırlı sayıda akademik çalışma bulunmaktadır. Bu çalışma ile yaratıcı olarak tasarlanan ve geleneksel bir mecrada (dergi) uygulanan bir reklam ile açıkhavada uygulanan ambient reklamın etkililik açısından bir karşılaştırması yapılmış ve tüketicilerin bu reklamlara yönelik tutumları cinsiyet ve reklam-

6 https://tr.pinterest.com/pin/162270392794045420/ (Erişim Tarihi:10.06.2016) 
lara yönelik inanç değişkeni açısından incelenmiştir. Ülkemizde ambient reklamcılık konusunun gelişimi açısından bu çalışmanın hem Türkçe literatüre hem de uygulama alanlarına katkıda bulunacağı düşünülmektedir.

\section{Araştırma Tasarımı}

$\mathrm{Bu}$ araştırmada nicel araştırma yaklaşımı benimsenmiştir ve nicel araştırma desenlerinden biri olan genel tarama modelinden yararlanılmıştır. "Tarama çalışması, bir araştırma evreninin eğilim, tutum ya da görüşlerini bu evrendeki bir örneklemle çalışarak nicel ya da sayısal olarak tanımlamaya olanak sağlar" (Creswell, 2014, s. 13).

Çalışma kapsamında etkililik karşılaştırması yapılan reklamlar için yurtdışında faaliyet gösteren bitkisel çay üreticisi markalara ait birer reklam örneği uyarıcı olarak kullanılmıştır. Uyarıcı olarak kullanılan reklamların ülkemizde bilinmeyen bir marka ismine ve cinsiyetsiz bir ürün grubuna ait olmasina dikkat edilmiş ve tüketicilerin bilinen markalara yönelik halihazırdaki tutumlarından arınmış bir sonuç elde edilmeye çalışılmıştır. Geleneksel reklam örneği olarak yaratıcı bir şekilde tasarlanan ve bir dergide yayınlanan reklam örneği seçilmiştir $(E k A)$. Ambient reklam örneği olarak ise açıkhavada uygulanmış bir ambient reklam örneği kullanılmıştır ( $E k B)$. Reklam örneklerinde yaratıcılık ve çalışma açısından uygunluk değerlendirmesi Halkla İlişkiler ve Reklamcilık Anabilim Dalında görevli üç akademisyen tarafından yapılmış ve reklam örneklerinin yaratıcı ve çalışma açısından uygun örnekler olduklarına karar verilmiştir.

Araştırmanın evrenini Anadolu Üniversitesi öğrencileri oluşturmaktadır. Üniversitedeki toplam fakülte ve enstitülerde örgün eğitim gören öğrenci sayısı 2015-2016 öğretim yılı Eylül ayı itibarıly 29.086'dır . Örneklem sayısını belirlemek için aşağıdaki örneklem sayısı belirleme formülünden yararlanılmıştır (Yazıcıoğlu ve Erdoğan, 2004'den aktaran Bayın ve Önder, 2014, s. 144).

7 https://www.anadolu.edu.tr/universitemiz/sayilarla-universitemiz/ogrenci-sayilari/2015-2016-ogrenci-sayilari/eylul-2015 (Erișim Tarihi: 01.07.2016)

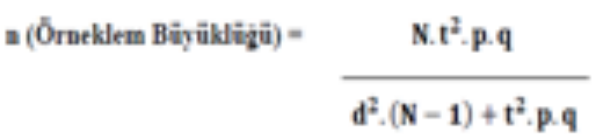

Evrendeki kişi sayısı (N) 29.086, bu çalışma için belirlenen güven aralığ $1 \% \mathbf{9 5}$, bu değerin $\mathrm{T}$ tablosundaki karşılığ 1 ise 1,96'dır. Örnekleme hatası (d) 0,05 ve ulaşılması gereken en büyük örnekleme ulaşmak için seçilen varyans değeri (p) ve (q) için $\mathbf{0 , 5 0}$ 'dir. Bu değerler sonucunda ulaşılması gereken örneklem sayısı yaklaşık 379 kişi olarak belirlenmiştir.

Araştırmada örnekleme yöntemi olarak tesadüfi olmayan örnekleme yöntemlerinden kolayda örnekleme tekniği ve birincil veri toplama yöntemlerinden biri olan anket tekniği kullanılmıştır. Toplamda 393 adet anket uygulanmıştır fakat hatalı veya eksik doldurulan anketlerin çıarılmasıyla 388 anket üzerinden analizler gerçekleştirilmiştir. Bu kapsamda anketler 20-27 Haziran 2016 tarihleri arasinda Anadolu Üniversitesi İIBBF, Fen Fakültesi, Eğitim Fakültesi ve Mühendislik Fakültesi'nde uygulanmıştır. Anketler araştırma amacının belirtilmesinden sonra çalışmaya gönüllü olarak katılmayı kabul eden öğrencilere dağıtılmış ve kişi yönelimli (self-administrated) teknik ile katılımcılardan veri toplanmıştır. Katılımcıların yarısı (194 kişi) geleneksel reklam örneğini (dergi reklamı) bir uyarıcı olarak gördükten sonra anketi cevaplarken, diğer yarısı (194 kişi) ambient reklam örneğini gördükten sonra anketi cevaplamıştır ve katılımcılar uyarıcı olarak gördükleri reklam örneklerine rassal olarak atanmamıştır. Örnekleme giren katılımcıların 198'i (\%51) kadın, 190’1 (\%49) erkeklerden oluşmaktadır. Kadınların yaş ortalaması 22,72 erkeklerin yaş ortalaması ise 23,49 'dur.

Çalışmada kullanılan anket demografik sorular hariç 6 bölümden oluşmaktadır. Reklamın etkililiği Hutter (2015, s. 42) tarafından geliştirilen 5 değişken üzerinden değerlendirilmiştir. Reklamlara yönelik genel inanç ölçeği ise Bauer ve Greyser'den (1968'den aktaran Bir vd., 2015, s. 49) alınmıştır. Hutter (2015, s. 42) reklamların etkililiğinin ölçümünde "algılanan sürpriz etkisi” (Izard, 1977), "reklama yönelik dikkat" (Buchholz ve Smith, 1991), "reklama karşı tutum" (Mitchell ve Olson, 1981), "markaya karşı tutum" (Bruner ve Kumar, 2000) ve "satın alma niyeti" (Mac- 
Kenzie vd., 1986) ölçeklerini derleyerek tek bir ölçek haline getirmiştir. Algılanan sürpriz etkisi 6 ifadeyle (sıra dışı bir reklamdır, sürpriz etkisi yaratan bir reklamdır, yaratıcı bir reklamdır vb.); reklama yönelik dikkat, 4 ifadeyle (reklam çok dikkatimi çekti, fark etmemek mümkün değil vb.); satın alma niyeti de "reklamdaki bu markayı alabilirim" gibi 3 ifade arac1lığıyla değerlendirilmiştir. Tüm bu değerlendirmelerde ise 5'li Likert ölçeği (1=Kesinlike katılmıyorum, $5=$ Kesinlikle katılıyorum) kullanılmıştır. Reklama ve markaya yönelik tutum ise (reklamı beğendim/ beğenmedim ya da markayı beğendim/beğenmedim gibi) üçer ifade ve semantik ölçek aracıllğıyla değerlendirilmiştir.

Araştırmada katılımcıların reklamlara yönelik genel inançlarının bu uygulamalara yönelik tutumları etkileyebileceği varsayılmıştır. Bilindiği gibi reklam mesajlarına hedef olan tüketiciler, sadece mesajları izlemekle kalmayıp onlara inanırlarsa ikna gerçekleşecektir. Şüphe, reklamın iddia ettiklerine az ya da çok inançsızlık eğilimidir ve reklam mesajlarının değerlendirilmesinde önemli rol oynamaktadır (Ergeç, 2009, s. 172). Bireyin reklama yönelik inanc1, reklama yönelik tutumun yaratıcısı ve belirleyicisidir (Akyüz, 2011, s. 144). Bu nedenle katılımciların reklamlara yönelik genel inançlarını ölçmek için reklamlara yönelik genel inanç ölçeğinden (Bauer ve Greyser, 1968'den aktaran Bir vd., 2015, s. 49) yararlanılmıştır. Ölçek 7 ifadeden (genel olarak reklam gereklidir, reklamlar sıklıkla insanları almayacakları ürünleri almaya ikna eder, reklamlar ürünle ilgili doğru bir çerçeve sunar vb.) oluşmaktadır ve yine 5'li Likert ölçeği (1=Kesinlike katılmıyorum, 5=Kesinlikle kat1lıyorum) aracılığıyla değerlendirilmiştir.

\section{Bulgular}

Verilerin analiz edilmesinde SPSS 20.0 istatistik programı kullanılmıştır. İlk olarak veriler sayısal ifadelere dönüştürülmüş ve frekans tabloları oluşturulmuştur. Ölçeklerin güvenilirlik değerleri Cronbach alfa katsayısı ile tespit edilmiştir. Reklamlara yönelik genel inanç ölçeğinde ölçeğin güvenilirliğini düşüren bir ifadenin ölçekten çıkarılmasıyla gerekli analizler yapılmıştır. Ölçeklerin güvenilirliklerine ilişkin değerler Tablo 1'de sunulmuştur.
Tablo 1. Ölçeklerin Cronbach Alfa Değerleri

\begin{tabular}{ccc}
\hline Ölçek & $\begin{array}{c}\text { Cronbach alfa değerleri } \\
\text { Dergi }\end{array}$ & $\begin{array}{c}\text { Ambient } \\
\text { Algllanan sürpriz etkisi }\end{array}$ \\
0,844 & 0,874 \\
Reklama yönelik dikkat & 0,727 & 0,804 \\
Reklama yönelik tutum & 0,821 & 0,833 \\
Markaya yönelik tutum & 0,792 & 0,774 \\
Satın alma niyeti & 0,837 & 0,895 \\
$\begin{array}{c}\text { Reklamlara yönelik genel } \\
\text { inanç }\end{array}$ & 0,618 & 0,621 \\
\hline
\end{tabular}

Reklam etkililiğini değerlendirmede anket üniversite öğrencilerine uygulandığından dolayı eğitim değişkeni değerlendirmeye alınmamış ve yaşla ilgili bir farklılık bulunmamıştır. Bu nedenle reklam etkililiği cinsiyet ve reklamlara yönelik genel inanç değişkenleri üzerinden incelenmiştir. Reklamların etkililiği, cinsiyet ve reklamlara yönelik genel inanç değişkeni açısından reklamlara yönelik tutumlar "Bağımsız Örneklem T-Test", "Hiyerarşik Olmayan Kümeleme Analizi” ve "Tek Yönlü Varyans Analizi (ANOVA)" istatistikleri ile analiz edilmiştir. İlk olarak geleneksel ve ambient reklam, reklamın etkililiği açısından Bağımsız Örneklem T-Test istatistiği ile analiz edilmiş ve analiz sonucu Tablo 2'de sunulmuştur.

Tablo 2. Dergi Reklamı ve Ambient Reklamın Etkililik Açısından Karşılaştırılması $\left(n_{G}=194 ; n_{A}=194\right)$

\begin{tabular}{cccc}
\hline Ölçek & Reklam Türü & $\begin{array}{c}\text { Ortalama } \\
(\overline{\boldsymbol{x}})\end{array}$ & $\mathbf{( t )}$ \\
Algılanan & Dergi & 3,36 & \\
Sürpriz Etkisi & Ambient & 3,60 & $\mathbf{- 3 , 2 2 0 *}$ \\
Reklama Karşı & Dergi & 3,23 & \\
Dikkat & Ambient & 3,27 & $-0,493$ \\
Reklama Karşı & Dergi & 3,50 & \\
Tutum & Ambient & 3,68 & $\mathbf{- 2 , 0 0 0 *}$ \\
Markaya & Dergi & 3,30 & \\
Karşı Tutum & Ambient & 3,39 & $-0,975$ \\
Satın Alma & Dergi & 3,39 & \\
Niyeti & Ambient & 3,28 & 1,320 \\
\hline * $=<\mathbf{0 , 0 5}$ (1=Kesinlikle Katılmırorum; $5=$ Kesinlikle Katılıorum)
\end{tabular}

Tüm katılımcllar üzerinde yapılan istatistiksel analiz sonucunda, ambient reklam ile geleneksel reklam 
etkililiği ortalamaları arasında farklılıklar tespit edilmiştir. Bu farklılıklar sadece "algılanan sürpriz etkisi” $(t(386)=-3,220, p<0,05, \mathrm{r}=0,13)$ ve "reklama karş1 tutum" $(t(386)=-2,000, p<0,05, r=0,10)$ değişkenleri bakımından istatistiksel açıdan anlamlı farklılıklardır. Algilanan sürpriz etkisi $(=3,60>$ ve reklama karşı tutum $(=3,68>$ değişkenlerinin ortalamaları itibarıla ambient reklam geleneksel reklamdan daha etkili bulunmuştur. Reklama karşı dikkat, markaya karşı tutum ve satın alma niyeti açısından ise gruplar arası istatistiksel olarak anlamlı bir farklılık bulunamamıştır.

Cinsiyet değişkeni açısından tüketicilerin reklamlara yönelik tutumları Tablo 3'de sunulmuştur.

Tablo 3. Dergi Reklamı ve Ambient Reklamın Etkililiğinin Cinsiyet Değişkenine Göre Farklılaşması

\begin{tabular}{|c|c|c|c|c|c|}
\hline Ölçek & Cinsiyet & $\begin{array}{c}\text { Reklam } \\
\text { Türü }\end{array}$ & (n) & $\underset{\bar{x}}{\text { Ortalama }}$ & (t) \\
\hline \multirow{4}{*}{$\begin{array}{c}\text { Algılanan } \\
\text { Sürpriz } \\
\text { Etkisi }\end{array}$} & \multirow[b]{2}{*}{ Kadın } & Dergi & 100 & 3,26 & \multirow[b]{2}{*}{$-3,399$ * } \\
\hline & & Ambient & 98 & 3,62 & \\
\hline & \multirow[b]{2}{*}{ Erkek } & Dergi & 94 & 3,47 & \multirow[b]{2}{*}{$-1,118$} \\
\hline & & Ambient & 96 & 3,59 & \\
\hline \multirow{4}{*}{$\begin{array}{c}\text { Reklama } \\
\text { Karşı } \\
\text { Dikkat }\end{array}$} & \multirow[b]{2}{*}{ Kadın } & Dergi & 100 & 3,17 & \multirow[b]{2}{*}{$-2,390$ * } \\
\hline & & Ambient & 98 & 3,42 & \\
\hline & \multirow{2}{*}{ Erkek } & Dergi & 94 & 3,29 & \multirow{2}{*}{1,490} \\
\hline & & Ambient & 96 & 3,11 & \\
\hline \multirow{4}{*}{$\begin{array}{c}\text { Reklama } \\
\text { Karşı } \\
\text { Tutum }\end{array}$} & \multirow[b]{2}{*}{ Kadın } & Dergi & 100 & 3,37 & \multirow[b]{2}{*}{$-2,853 *$} \\
\hline & & Ambient & 98 & 3,72 & \\
\hline & \multirow[b]{2}{*}{ Erkek } & Dergi & 94 & 3,64 & \multirow[b]{2}{*}{0,023} \\
\hline & & Ambient & 96 & 3,63 & \\
\hline \multirow{4}{*}{$\begin{array}{c}\text { Markaya } \\
\text { Karşı } \\
\text { Tutum }\end{array}$} & \multirow[b]{2}{*}{ Kadın } & Dergi & 100 & 3,25 & \multirow[b]{2}{*}{$-2,706^{*}$} \\
\hline & & Ambient & 98 & 3,55 & \\
\hline & \multirow[b]{2}{*}{ Erkek } & Dergi & 94 & 3,36 & \multirow[b]{2}{*}{1,212} \\
\hline & & Ambient & 96 & 3,21 & \\
\hline \multirow{4}{*}{$\begin{array}{l}\text { Satın } \\
\text { Alma } \\
\text { Niyeti }\end{array}$} & \multirow[b]{2}{*}{ Kadın } & Dergi & 100 & 3,42 & \multirow[b]{2}{*}{$-0,150$} \\
\hline & & Ambient & 98 & 3,43 & \\
\hline & \multirow[b]{2}{*}{ Erkek } & Dergi & 94 & 3,36 & \multirow[b]{2}{*}{1,789} \\
\hline & & Ambient & 96 & 3,12 & \\
\hline
\end{tabular}

${ }^{*}$ p $<0,05$ (1=Kesinlikle Katılmıyorum; 5=Kesinlikle Katılıyorum)

Kadın tüketiciler üzerinde yapılan istatistiksel analiz sonucunda, ambient reklam ile geleneksel reklam etkililiği ortalamaları arasında farklılıklar tespit edilmiştir. Bu farklllıklar "algılanan sürpriz etkisi" $(t(196)=-3,399, p<0,05, r=0,17)$, "reklama karşı dikkat" $(t(196)=-2,390, p<0,05, r=0,16)$, "reklama karş1 tutum" ( $t(196)=-2,853, p<0,05, \mathrm{r}=0,19)$ ve "markaya karş1 tutum" $(t(196)=-2,706, p<0,05, r=0,19)$ değişkenleri bakımından istatistiksel açıdan anlamlı farklılıklardır. "Algilanan sürpriz etkisi" $(=3,62>=$ $3,26)$, "reklama karșı dikkat" $(=3,42>=3,17)$, "reklama karşı tutum" $(=3,72>=3,37)$ ve "markaya karşı tutum" $(=3,55>=3,25)$ değişkenlerinin ortalamaları itibarıyla ambient reklam kadın tüketiciler tarafından geleneksel reklamdan daha etkili bulunmuştur. Satın alma niyeti değişkeni açısından ise istatistiksel bir farklılık bulunamamıştır. Erkek tüketiciler açısından analizler incelendiğinde geleneksel dergi reklamı ve ambient reklam etkililiği açısından ortalamalar arası farklılıklar istatistiksel açıdan anlamlı değildir.

Çalışma kapsamında reklamlara yönelik genel inanç değişkeni açısından farklı inanç seviyelerine göre iki reklam örneğinin de etkililiği incelenmiştir. Bu bağlamda reklamlara yönelik genel inanç ölçeği "Hiyerarşik Olmayan Kümeleme Analizi” ile 3 gruba (dü- 
şük/orta/yüksek) ayrılmıştır. Ayırma işlemi 2 farklı grup (geleneksel/ambient) için ayrı ayrı yapılmış ve her kümeye ilişkin veriler Tablo 4'de sunulmuştur.

\begin{tabular}{lcc}
$\begin{array}{l}\text { Tablo 4. Reklamlara Yönelik Genel Inanç Seviyesine Illişkin } \\
\text { Kümeleri Oluşturan Katılımcı Sayıları }\end{array}$ \\
\hline Düşük & Dergi & Ambient \\
Orta & $31(\% 16)$ & $48(\% 25)$ \\
Yüksek & $120(\% 62)$ & $93(\% 48)$ \\
Toplam & $43(\% 22)$ & $53(\% 27)$ \\
\hline
\end{tabular}

İlk olarak geleneksel reklam, reklamlara yönelik genel inanç değişkeni açısından incelenmiştir. Kat1lımcıların reklam etkililiği ölçeğine verdikleri cevap ortalamaları ve ANOVA analizi sonuçları Tablo 5'de sunulmuştur.

Reklamlara yönelik genel inanç seviyelerine göre geleneksel reklamın etkililiği analiz edildiğinde sadece "satın alma niyeti" değişkeni açısından gruplar arası (düşük/orta/yüksek) anlamlı farklılıkların varlığı tespit edilmiştir, $\mathrm{F}(2,191)=4,539, \mathrm{p}<0,05, \eta^{2}=0,04$. LSD işlem sonrası (post hoc) test sonuçlarına $(\alpha=0,004)$

\begin{tabular}{|c|c|c|c|c|}
\hline Ölçek & $\begin{array}{c}\text { Genel } \\
\text { İnanç } \\
\text { Seviyesi }\end{array}$ & (n) & $\begin{array}{c}\text { Ortalama } \\
(\bar{x})\end{array}$ & (F) \\
\hline \multirow{3}{*}{$\begin{array}{c}\text { Algilanan } \\
\text { Sürpriz } \\
\text { Etkisi }\end{array}$} & Düşük & 31 & 3,14 & \multirow{3}{*}{ 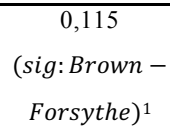 } \\
\hline & Orta & 120 & 3,35 & \\
\hline & Yüksek & 43 & 3,55 & \\
\hline \multirow{3}{*}{$\begin{array}{c}\text { Reklama } \\
\text { Karşı Dikkat }\end{array}$} & Düşük & 31 & 3,08 & \multirow{3}{*}{0,729} \\
\hline & Orta & 120 & 3,26 & \\
\hline & Yüksek & 43 & 3,23 & \\
\hline \multirow{3}{*}{$\begin{array}{c}\text { Reklama } \\
\text { Karşı Tutum }\end{array}$} & Düşük & 31 & 3,12 & \multirow{3}{*}{$\begin{array}{c}0,067 \\
\text { (sig: Brown- } \\
\text { Forsythe) }\end{array}$} \\
\hline & Orta & 120 & 3,59 & \\
\hline & Yüksek & 43 & 3,52 & \\
\hline \multirow{3}{*}{$\begin{array}{c}\text { Markaya } \\
\text { Karşı Tutum }\end{array}$} & Düşük & 31 & 2,98 & \multirow{3}{*}{2,843} \\
\hline & Orta & 120 & 3,35 & \\
\hline & Yüksek & 43 & 3,41 & \\
\hline \multirow{3}{*}{$\begin{array}{l}\text { Satın Alma } \\
\text { Niyeti }\end{array}$} & Düşük & 31 & 3,03 & \multirow{3}{*}{$4,539 *$} \\
\hline & Orta & 120 & 3,45 & \\
\hline & Yüksek & 43 & 3,46 & \\
\hline
\end{tabular}

${ }^{*} \mathrm{p}=<0,05$ ( $1=$ Kesinlikle Katılmıyorum; 5=Kesinlikle Katıllyorum)

göre reklamlara yönelik genel inançları düşük olanlar $(=3,03, \mathrm{~S}=0,924)$ ile orta seviyede olanların $(=3,45$, $\mathrm{S}=0,654)$ satın alma niyeti ortalamaları arasında istatistiksel açıdan anlamlı $(\mathrm{p}<0,05)$ bir farklılık vardır. Aynı şekilde LSD işlem sonrası (post-hoc) test sonuçlarına göre $(\alpha=0,012)$ reklamlara yönelik genel inançları düşük olanlar $(=3,03, S=0,924)$ ile yüksek olanların $(=3,46, \mathrm{~S}=0,752)$ satın alma niyeti ortalamaları arasında istatistiksel açıdan anlamlı $(\mathrm{p}<0,05)$ bir farklılık vardır. Diğer değişkenler açısından gruplar arası ortalama farklılıklar istatistiksel açıdan anlamlı değildir.

İkincil olarak ambient reklam, reklamlara yönelik genel inanç değişkeni açısından incelenmiştir. Katılımcıların reklam etkililiği ölçeğine verdikleri cevap ortalamaları ve ANOVA analizi sonuçları Tablo 6'da sunulmuştur. 
Tablo 6. Ambient Reklamın Reklamlara Yönelik Genel Inanç Değişkeni Açısından Incelenmesi

\begin{tabular}{|c|c|c|c|c|}
\hline Ölçek & $\begin{array}{c}\text { Genel } \\
\text { İnanç } \\
\text { Seviyesi }\end{array}$ & (n) & $\begin{array}{l}\text { Ortalama } \\
(\bar{x})\end{array}$ & $\mathbf{F}$ \\
\hline \multirow{3}{*}{$\begin{array}{c}\text { Algılanan } \\
\text { Sürpriz Etkisi }\end{array}$} & Düşük & 48 & 3,35 & \multirow{3}{*}{$8,578 * *$} \\
\hline & Orta & 93 & 3,55 & \\
\hline & Yüksek & 53 & 3,92 & \\
\hline \multirow{3}{*}{$\begin{array}{c}\text { Reklama Karşı } \\
\text { Dikkat }\end{array}$} & Düşük & 48 & 3,05 & \multirow{3}{*}{$7,310 *$} \\
\hline & Orta & 93 & 3,18 & \\
\hline & Yüksek & 53 & 3,63 & \\
\hline \multirow{3}{*}{$\begin{array}{c}\text { Reklama Karşı } \\
\text { Tutum }\end{array}$} & Düşük & 48 & 3,37 & \multirow{3}{*}{$6,777^{*}$} \\
\hline & Orta & 93 & 3,67 & \\
\hline & Yüksek & 53 & 3,97 & \\
\hline \multirow{3}{*}{$\begin{array}{c}\text { Markaya } \\
\text { Karşı Tutum }\end{array}$} & Düşük & 48 & 3,09 & \multirow{3}{*}{$7,446 *$} \\
\hline & Orta & 93 & 3,37 & \\
\hline & Yüksek & 53 & 3,68 & \\
\hline \multirow{3}{*}{$\begin{array}{c}\text { Satın Alma } \\
\text { Niyeti }\end{array}$} & Düşük & 48 & 2,89 & \multirow{3}{*}{$7,641 *$} \\
\hline & Orta & 93 & 3,30 & \\
\hline & Yüksek & 53 & 3,58 & \\
\hline
\end{tabular}

${ }^{*}$ p $<0.05$ (1=Kesinlikle Katılmıyorum; 5=Kesinlikle Katılıyorum)

${ }^{* *} \mathrm{p}<0,001$

Reklamlara yönelik genel inanç seviyelerine göre ambient reklamın etkililiği analiz edildiğinde tüm değişkenlerde gruplar arası anlamlı farklılıkların varlığ tespit edilmiştir. Algılanan sürpriz etkisi değişkeni açısından gruplar arası (düşük/orta/yüksek) anlamlı farklılık bulunmaktadır, $\mathrm{F}(2,191)=8,578, \mathrm{p}<0,001$, $\eta^{2}=0,08$. LSD işlem sonrası (post hoc) test sonuçlarına $(\alpha=0,000)$ göre reklamlara yönelik genel inançları yüksek olanlar $(=3,92, S=0,638)$ ile düşük olanların $(=3,35, \mathrm{~S}=0,753)$ algilanan sürpriz etkisi ortalamala$\mathrm{r} 1$ arasında istatistiksel açıdan anlamlı $(\mathrm{p}<0,001)$ bir farklılık vardır. Aynı şekilde LSD işlem sonrası (posthoc) test sonuçlarına $(\alpha=0,000)$ göre reklamlara yönelik genel inançları yüksek olanlar $(=3,92, S=0,638)$ ile orta seviyede olanların $(=3,55, \mathrm{~S}=0,730)$ algilanan sürpriz etkisi ortalamaları arasında istatistiksel açıdan anlamlı $(\mathrm{p}<0,001)$ bir farklılık vardır.

Reklama karşı dikkat değişkeni açısından gruplar arası (düşük/orta/yüksek) anlamlı farklılık bulun- maktadır, $\mathrm{F}(2,191)=7,310, \mathrm{p}<0,05, \eta^{2}=0,07$. LSD işlem sonrası (post hoc) test sonuçlarına $(\alpha=0,001)$ göre reklamlara yönelik genel inançları yüksek olanlar $(=3,63, S=0,783)$ ile düşük olanların $(=3,05$, $\mathrm{S}=0,798)$ reklama karşı dikkat ortalamaları arasında istatistiksel açıdan anlamlı $(\mathrm{p}<0,05)$ bir farklılık vardır. Aynı şekilde LSD işlem sonrası (post-hoc) test sonuçlarına $(\alpha=0,001)$ göre reklamlara yönelik genel inançları yüksek olanlar $(=3,63, S=0,783)$ ile orta seviyede olanların $(=3,18, S=0,862)$ reklama karşı dikkat ortalamaları arasında istatistiksel açıdan anlamlı $(\mathrm{p}<0,05)$ bir fark olduğu görülmektedir.

Reklama karşı tutum değişkeni açısından gruplar arası (düşük/orta/yüksek) anlamlı farklılık bulunmaktadır, $\mathrm{F}(2,191)=6,777, \mathrm{p}<0,05, \eta^{2}=0,06 . \mathrm{LSD}$ işlem sonrası (post hoc) test sonuçlarına $(\alpha=0,001)$ göre reklamlara yönelik genel inançları yüksek olan$\operatorname{lar}(=3,97, S=0,786)$ ile düşük olanların $(=3,37$, $\mathrm{S}=0,821)$ reklama karşı tutum ortalamaları arasında 
istatistiksel açıdan anlamlı $(\mathrm{p}<0,05)$ bir farklılık vardır. Aynı şekilde LSD işlem sonrası (post-hoc) test sonuçlarına $(\alpha=0,001)$ göre reklamlara yönelik genel inançları yüksek olanlar $(=3,97, \mathrm{~S}=0,786)$ ile orta seviyede olanların $(=3,67, \mathrm{~S}=0,834)$ reklama karşı tutum ortalamaları arasında istatistiksel açıdan anlamlı $(\mathrm{p}<0,05)$ bir farklılık vardır. Ayrıca LSD işlem sonrası (post hoc) test sonuçlarına $(\alpha=0,001)$ göre reklamlara yönelik genel inançları orta seviyede olanlar (=
3,67, $S=0,834)$ ile düşük olanların $(=3,37, S=0,821)$ da reklama karşı tutum ortalamaları arasında istatistiksel açıdan anlamlı $(\mathrm{p}<0,05)$ bir farklılık vardır.

Markaya karşı tutum değişkeni açısından gruplar arası (düşük/orta/yüksek) anlamlı farklılık bulunmaktadir, $\mathrm{F}(2,191)=7,446, \mathrm{p}<0,05, \eta^{2}=0,07$. LSD işlem sonrası (post hoc) test sonuçlarına $(\alpha=0,001)$ göre reklamlara yönelik genel inançları yüksek

Tablo 7. Dergi Reklamı ve Ambient Reklam Etkililiğinin Reklamlara Yönelik Genel Inancı Düşük ve Yüksek Tüketiciler Açısından Karşılaştırılması

\begin{tabular}{|c|c|c|c|c|c|}
\hline Ölçek & $\begin{array}{c}\text { Genel İnanç } \\
\text { Seviyesi }\end{array}$ & Reklam Türü & (n) & $\begin{array}{c}\text { Ortalama } \\
\bar{x}\end{array}$ & (t) \\
\hline \multirow{4}{*}{$\begin{array}{l}\text { Algılanan } \\
\text { Sürpriz } \\
\text { Etkisi }\end{array}$} & Düşük & Dergi & 31 & 3,14 & \multirow{2}{*}{$-1,105$} \\
\hline & Düşük & Ambient & 48 & 3,35 & \\
\hline & Yüksek & Dergi & 43 & 3,55 & \\
\hline & Yüksek & Ambient & 53 & 3,92 & \\
\hline \multirow{4}{*}{$\begin{array}{c}\text { Reklama } \\
\text { Karşı } \\
\text { Dikkat }\end{array}$} & Düşük & Dergi & 31 & 3,08 & \multirow{2}{*}{0,201} \\
\hline & Düșük & Ambient & 48 & 3,05 & \\
\hline & Yüksek & Dergi & 43 & 3,23 & \multirow{4}{*}{$-1,204$} \\
\hline & Yüksek & Ambient & 53 & 3,63 & \\
\hline \multirow{4}{*}{$\begin{array}{c}\text { Reklama } \\
\text { Karşı } \\
\text { Tutum }\end{array}$} & Düşük & Dergi & 31 & 3,12 & \\
\hline & Düşük & Ambient & 48 & 3,37 & \\
\hline & Yüksek & Dergi & 43 & 3,52 & $-2,368^{*}$ \\
\hline & Yüksek & Ambient & 53 & 3,97 & \\
\hline \multirow{4}{*}{$\begin{array}{c}\text { Markaya } \\
\text { Karşı } \\
\text { Tutum }\end{array}$} & Düşük & Dergi & 31 & 2,98 & \multirow[b]{2}{*}{$-0,559$} \\
\hline & Düşük & Ambient & 48 & 3,09 & \\
\hline & Yüksek & Dergi & 43 & 3,41 & \multirow{4}{*}{0,619} \\
\hline & Yüksek & Ambient & 53 & 3,68 & \\
\hline \multirow{4}{*}{$\begin{array}{l}\text { Satın Alma } \\
\text { Niyeti }\end{array}$} & Düşük & Dergi & 31 & 3,03 & \\
\hline & Düşük & Ambient & 48 & 2,89 & \\
\hline & Yüksek & Dergi & 43 & 3,46 & \multirow[t]{2}{*}{$-0,726$} \\
\hline & Yüksek & Ambient & 53 & 3,58 & \\
\hline
\end{tabular}

${ }^{*}$ p $<0.05$ (1=Kesinlikle Katılmıyorum; 5=Kesinlikle Katılıyorum) 
olanlar $(=3,68, S=0,801)$ ile düşük olanların $(=3,09$, $\mathrm{S}=0,780)$ markaya karşı tutum ortalamaları arasında istatistiksel açıdan anlamlı $(\mathrm{p}<0,05)$ bir farklılık vardır. Aynı şekilde LSD işlem sonrası (post-hoc) test sonuçlarına $(\alpha=0,001)$ göre reklamlara yönelik genel inançları yüksek olanlar $(=3,68, S=0,801)$ ile orta seviyede olanların $(=3,37, S=0,740)$ markaya karşı tutum ortalamaları arasında istatistiksel açıdan anlamlı $(\mathrm{p}<0,05)$ bir farklılık vardır. Ayrıca LSD işlem sonrası (post hoc) test sonuçlarına $(\alpha=0,001)$ göre reklamlara yönelik genel inançları orta seviyede olanlar (= $3,37, S=0,740)$ ile düşük olanların $(=3,09, S=0,780)$ da markaya karşı tutum ortalamaları arasında istatistiksel açıdan anlamlı $(\mathrm{p}<0,05)$ bir farklılık vardır.

Satın alma niyeti değişkeni açısından gruplar arası (düşük/orta/yüksek) anlamlı farklılık bulunmaktadır, $\mathrm{F}(2,191)=7,641 \mathrm{p}<0,05, \eta^{2}=0,07$. LSD işlem sonrası (post hoc) test sonuçlarına $(\alpha=0,001)$ göre reklamlara yönelik genel inançları yüksek olanlar $(=3,58$, $\mathrm{S}=0,842)$ ile düșük olanların $(=2,89, \mathrm{~S}=0,977)$ satın alma niyeti ortalamaları arasında istatistiksel açıdan anlamlı $(\mathrm{p}<0,05)$ bir farklılık vardır. Aynı şekilde LSD işlem sonrası (post-hoc) test sonuçlarına $(\alpha=0,001)$ göre reklamlara yönelik genel inançları orta seviyede olanlar $(=3,30, S=0,866)$ ile düşük olanların $(=2,89$, $S=0,977)$ satın alma niyeti ortalamaları arasinda istatistiksel açıdan anlamlı $(\mathrm{p}<0,05)$ bir farklılık vardır.

Reklamlara yönelik genel inancı düşük ve yüksek olan katılımciların geleneksel ve ambient reklama yönelik tutumları karşılaştıııldığında, reklam etkililiği ortalamaları arasında farklılıklar tespit edilmiştir. $\mathrm{Bu}$ farklılıklar reklamlara yönelik genel inancı yüksek katılımcılar açısından "algılanan sürpriz etkisi" $(t(94)=-2,379, p<0,05, r=0,22)$, "reklama karşı dikkat" $(t(94)=-2,424, p<0,05, r=0,22)$, ve "reklama karş1 tutum" $(t(94)=-2,368, p<0,05, r=0,23)$ değişkenleri bakımından istatistiksel açıdan anlamlı farklılıklardır. Reklama yönelik genel inancı yüksek olan tüketicilerin "algilanan sürpriz etkisi" $(=3,92>=3,55)$, "reklama karşı dikkat" $(=3,63>=3,23)$ ve "reklama karşı tutum" $(=3,97>=3,52)$ değişkenlerinin ortalamaları itibarıyla ambient reklamı geleneksel reklamdan daha etkili buldukları söylenebilir. Markaya karşı tutum ve satın alma niyeti değişkenleri açısından ise istatistiksel bir farklılık bulunamamıştır. Reklamlara yönelik genel inancı düşük katılımcıların iki reklama yönelik tutumları karşılaştırıldığında ise istatistiksel açıdan anlamlı bir farklılık tespit edilmemiştir.

\section{Sonuç ve Öneriler}

Bu çalışmada yaratıcı bir şekilde tasarlanmış ve geleneksel bir mecra (dergi) üzerinde uygulanmış bir reklam ile ambient reklamın etkililik açısından bir karşılaştırması yapılmış ve bu reklamlara karşı tüketici tutumlarının ne olduğu belirlenmeye çalışılmıştır. Ayrıca reklamlara yönelik genel inançları farklı olan tüketicilerin iki farklı reklama yönelik tutumları da belirlenmeye çalışılmıştır.

İki reklamın çalışmaya katılan tüm katılımcılar üzerinden etkililiği incelendiğinde, ambient reklamın (ortam reklamı) algılanan sürpriz etkisi ve reklama karşı tutum değişkeni açısından geleneksel reklamdan daha etkili bulunduğu görülmüsstür. Bu nedenle ambient reklamların tüketiciler üzerinde sürpriz etkisi yarattığı ve bu etkinin reklama yönelik olumlu tutum geliştirmede etkili olduğu söylenebilir. Diğer değişkenlerde etkililik ortalamaları açısından istatistiksel olarak anlamlı olmayan farklılıklar tespit edilmiştir ve bu sonuç Hutter'ın (2015, s. 43) çalışmasıyla benzerlikler göstermektedir. Ayrıca bu sonuç geleneksel reklamlara aşırı şekilde maruz kalan tüketicilerin dikkatlerini çekmede ambient medyanın sürpriz etkisini ortaya çıkardığını savunan Hutter ve Hoffmann'ın (2013, s. 93) çalışmasıyla da benzerlik göstermektedir. İstatistiksel açıdan anlamlı bir farkl1lık yaratmamakla birlikte markaya karşı tutum değiş̧keni açısından ambient reklamların yaratmış olduğu pozitif etki Rosengren vd.'nin (2015, s. 26) çalışmasindaki bulgularla da benzerlik göstermektedir.

Geleneksel reklamın istatistiksel açıdan anlamlı olmamakla birlikte sadece satın alma niyeti açısından ambient reklamdan daha yüksek bir etkililik ortalamasına sahip olduğu görülmüştür. Bu sonuç Başev'in (2015, s. 283) ve Maniu ve Zaharie'nin (2014, s. 49) ambient reklamların satın alma niyeti üzerinde pozitif bir etkisinin olmadığını gösterdiği çalışmasıyla benzerlik göstermektedir. Bu sonuç ülkemizde gerilla pazarlama uygulamalarının ve spesifik olarak ambient reklamcilık uygulamalarının çok sık görülmemesine ve tüketicilerin bu tarz reklamlara çok fazla maruz kalmamış olmasına bağlanabilir.

Cinsiyet değiş̧keni üzerinden reklamların etkililiği incelendiğinde, satın alma niyeti değişkeni hariç diğer tüm değişkenler açısından kadın tüketicilerin ambient reklamı geleneksel reklamdan daha etkili bulduğu sonucuna ulaşılmıştır. Erkek tüketicilerin ise 
istatistiksel açıdan anlamlı olmamakla birlikte sadece algılanan sürpriz etkisi açısından ambient reklam ortalamalarının geleneksel reklam ortalamalarından yüksek olduğu görülmüștür. Diğer tüm değișkenlerde geleneksel reklamin etkililik ortalaması ambient reklamın etkililik ortalamasından daha yüksektir. Ambient reklamın sıra dışı, yaratıcı, dikkat çekici ve sürpriz etkisine sahip olmasından dolayı kadın tüketiciler üzerinde reklamın dikkat çekiciliğini arttırmak açısından daha fazla etki yarattığı söylenebilir.

Ifezue (2010, s. 17)'ye göre erkeklerin ve kadınların bilgiyi işlemeleri üzerindeki cinsiyet farklılıklarının bir sonucu olarak, kadınlara yönelik reklamların daha detaylı, erkeklere yönelik reklamların ise daha az detaylandırılmış olması gerekmektedir. Tüketici davranışları açısından iki cinsiyet incelendiğinde kadın tüketicilerin erkek tüketicilere göre daha detaycı oldukları, ayrıntılara daha çok önem verdikleri ve daha dikkatli oldukları bilinmektedir. Bu farklılıklar bu araştırmanın bulgularında da ortaya çıkmıştır. "Kadın tüketicilerin hormonsal özelliklerinden, beyin yapısı ve işlevine, dikkat ve odaklanmadan, ayrıntılı düșünme ve yetenek farkllılı̆ına kadar birçok etken, onların pazarlama faaliyetlerine verdikleri tepkilerin ve satın alma davranışlarının farklı olmasına neden olmaktadır" (Özdemir ve Tokol, 2008, s. 72). $\mathrm{Bu}$ sonuç, hedef kitlesi kadın tüketiciler olan firmaların reklam faaliyetlerinde ambient reklamları tercih etmelerinin reklamın geri dönüşleri açısından önemli getiriler sağlayacağını gösterebilir.

Son olarak reklamlara yönelik genel inanç seviyelerine (düşük/orta/yüksek) göre farklı tüketici gruplar1nın geleneksel ve ambient reklam açısından tutumları incelendiğinde, etkililik açısından ambient reklamın tüm değişkenlerde gruplar arası (düşük/orta/yüksek inanç seviyeleri) istatistiksel açıdan anlamlı farklılıklar yarattığ 1 tespit edilmiştir. Yani ambient reklamların reklamlara yönelik genel inancı orta ve yüksek seviyede olan tüketicileri reklamlara yönelik genel inancı düşük seviyede olan tüketicilerden daha çok etkilediği söylenebilir. Başka bir deyişle reklamlara yönelik genel inançları orta ve yüksek seviyede olanlar ambient reklamı reklamlara yönelik genel inancı düşük seviyede olanlara göre sürpriz etkisi ve dikkati çekme açısından daha etkili görmekte, markaya ve reklama karşı daha olumlu tutum beslemekte ve satın almaya da daha meyilli görülmektedirler. Geleneksel dergi reklamı açısından ise sadece satın alma niyeti değişkeninde gruplar arası istatistiksel açıdan anlamlı farklılık tespit edilmiștir. Bu sonuca göre geleneksel reklamın satın alma niyeti yaratması açısından reklamlara yönelik genel inancı orta ve yüksek seviyede olan tüketicileri, düşük seviyede olan tüketicilere k1yasla daha çok etkilediği söylenebilir.

Ayrıca çalışma kapsamında reklamlara yönelik genel inançları düşük ve yüksek olan katılımcıların iki farklı reklama (geleneksel/ambient) yönelik tutumları da karşılaştırılmış ve reklamların etkililiği ölçümlenmiştir. Reklamlara yönelik genel inancı düşük olan katılımcıların iki farklı reklama yönelik tutumlarında sadece ortalamalar arası farklılıklar görülmüştür. Fakat bu farklılıklar istatistiksel açıdan anlamlı farklılıklar değildir. Bununla birlikte reklamlara yönelik genel inancı yüksek olan katılımcıların iki farklı reklama yönelik tutumları incelendiğinde, bu kişilerin "algılanan sürpriz etkisi", "reklama yönelik dikkat" ve "reklama yönelik tutum" değişkenleri açısından ambient reklamı geleneksel reklamdan daha etkili bulduklar1 gözlenmiştir. Bu sonuç reklamlara yönelik genel inancı yüksek olan tüketicilerin ambient reklamlar sayesinde yapılan iletişim faaliyetlerinden geleneksel reklamlara kıyasla reklamın dikkat çekmesinden dolayı oluşabilecek marka farkındalığı açısından daha çok etkilenebileceğini göstermektedir.

\section{Sınırlılıklar ve İleri Araştırmalar}

$\mathrm{Bu}$ araştırmada örnekleme tekniği olarak kolayda örnekleme tekniğinden yararlanılmıştır. Çalışmanın genellenebilirliği açısından bu durum bir sınırlılık yaratmaktadır. Diğer bir sınırlılık ise çalışmada reklam etkililiğinin incelenebilmesi adına katılımcılara uyarıcı olarak gösterilen A4 boyutlu kağıda basılmış ambient reklam örneğidir. Ambient reklamlar doğaları gereği tüketicilerin gerçek ortamda (açık havada) karşılaştıkları reklam türlerinden biridir. Fakat bu çalışmada tüketiciler gerçek bir ambient reklamın basılı formdaki bir örneğine maruz kalarak değerlendirmelerini yapmışlardır. İleri araştırmalarda gerçek bir ambient reklama maruz kalan tüketicilerin tepkilerinin ölçülmesi bu çalışmanın sonuçlarının desteklenmesine ya da daha farklı sonuçlara ulaşılmasına neden olabilir. Ayrıca reklam etkililiğini ölçmek için bu çalışmada kullanılan değişkenlerin ileri bir çalışmada bir model üzerinden incelenmesi de değişkenlerin birbirleri arasındaki ilişkilerin anlaşılmasını sağlayabilecektir. 


\section{Kaynakça}

Akyüz, A. (2011). TV reklamlarından kaçınma: Davranışsal ve mekanik kaçınmaya etki eden faktörler. Öneri Dergisi, 9 (35), 143-151.

Alnıaçık, Ü., Yılmaz, C., \& Alnıaçı, E. (2010). Reklamlarda çevreci iddialar ve reklam etkililiği: Basılı reklamlar üzerinde deneysel bir araştırma. Anadolu Üniversitesi Sosyal Bilimler Dergisi, 10 (1), 85106.

Ay, C., \& Ünal, A. (2002). Küçük ve orta ölçekli işletmeler için yeni bir pazarlama anlayışı: Gerilla pazarlaması. Yönetim ve Ekonomi, 9 (1-2), 75-85.

Ay, C., Aytekin, P., \& Nardall, S. (2010). Guerrilla marketing communication tools and ethical problems in guerrilla advertising. American Journal of Economics and Business Administration, 2 (3), 280-286.

Baltes, G., \& Leibing, I. (2008). Guerilla marketing for information services? New Library World, 109 (1/2), 46-55.

Bargenda, A. (2015). Space design as an expressive device in ambient marketing: Case studies of Deutsche Bank and Banca Monte dei Paschi di Siena. Journal of Marketing Communication, 21 (1), 78-90.

Başev, S. E. (2015). Effect of ambient marketing on consumers' purchasing behaviour: A cross-cultural study. The Journal of Academic Social Science, (14), 268-286.

Bayın, G., \& Önder, Ö. R. (2014). Sağlık kurumlarında imaj üzerine bir araştırma. Mustafa Kemal Üniversitesi Sosyal Bilimler Enstitüsü Dergisi, 11 (27), 141-158.

Bigat, E. Ç. (2012). Guerrilla advertisement and marketing. Procedia- Social and Behavioral Sciences (51), 1022-1029.

Bir, A. A., Süher, K., \& Şener, G. (2015). An assesment of public attitudes toward advertising-in-general in Turkey. Anadolu University Journal of Social Science, 15 (1), 43-54.
Biraghi, S., Gambetti, R. C., \& Graffigna, G. (2015). An ecological definition of ambient communication: A discursive conceptualization. Journal of Marketing Communication, 21 (1), 5-19.

Burtenshaw, K., Mahon, N., \& Barfoot, C. (2014). Yaratıcı reklamcilığın temelleri. Cansu Uçar (Çev.). İstanbul: Literatür Yayınları.

Chatterjee, S. (2011). A study on ambient advertising: Marketing novelty going bust. Research Journal of Social Science \& Management, 1 (2), 86-90.

Creswell, J. (2014). Araştırma deseni. Selçuk Beşir Demir (Çev.) Ankara: Eğiten Kitap.

Çeltek, E., \& Bozdoğan, M. (2012). Alternatif pazarlama iletişimi aracı olarak gerilla pazarlama: Uygulanmış gerilla pazarlama reklam örneklerinin incelenmesi ve turizm sektörü için model önerileri. Journal of Yasar University, 28 (7), 4788-4812.

Dahan, G. S., \& Levi, E. (2012). Reklam ajanslarının gerilla pazarlama uygulamaları: Türkiye örneklemi üzerinden bir inceleme. İstanbul Bilgi Üniversitesi İletişim Fakültesi Dergisi (42), 37-47.

Dahlen, M. (2005). The medium as a contextual cue: Effects of creative media choice. Journal of Advertising, 34 (3) 89-98.

Dahlen, M., Rosengren, S., \& Törn, F. (2008). Advertising creativity matters. Journal of Advertising Research, 48 (3), 392-403.

Ergeç, N. E. (2009). Reklama şüpheci yaklaşımın incelenmesi. Ç.Ü Sosyal Bilimler Enstitüsü Dergisi, 18 (2), 172-193.

Gambetti, R. C. (2010). Ambient communication: How to engage consumers in urban touch-points. California Management Review, 52 (3), 34-51.

Graffigna, G., Gambetti, R. C., \& Bosio, A. C. (2011). Using ambient communication to reduce drinkdriving: Public health and shocking images in public spaces. Health, Risk \& Society, (13), 669-690. 
Hamelin, N., Moujahid, O. E., \& Thaichon, P. (2017). Emotion and advertising effectiveness: A novel facial expression analysis approach. Journal of Retailing and Consumer Services, 36, 103-111.

Hutter, K. (2015). Unusual location and unexpected execution in advertising: A content analysis and test of effectiveness in ambient advertisements. Journal of Marketing Communication, 21 (1), 33-47.

Hutter, K., \& Hoffmann, S. (2011). Guerrilla marketing: The nature of the concept and propositions for further research. Asian Journal of Marketing, (5), 39-54.

Hutter, K., \& Hoffmann, S. (2013). Surprise, surprise. Ambient media as promotion tool for retailers. Journal of Retailing, 90 (1), 93-110.

Ifezue, A. N. (2010). What makes an effective advertising for a man or a woman? . Journal of Communication, 1 (1), 13-18.

Jurca, M. A. (2012). What is and why do we need ambient advertising? A theoretical approach. International Conference "Marketing - from information to decision”, 5.Edition, s. 210-221. Cluj Napoca.

Jurca, M. A., \& Ioan, P. (2013). Schema congruity- A basis for evaluating ambient advertising effectiveness. Annals of the University of Oradea, Economic Science Series, 22 (1), 1765-1774.

Jurca, M. A., \& Madlberger, M. (2015). Ambient advertising characteristics and schema incongruity as drivers of advertising effectiveness. Journal of Marketing Communication, 21 (1), 48-64.

Karimova, G. Z. (2014). Toward a Bakhtinian typology of ambient advertising. Journal of Marketing Communications, 20 (4), 251-269.

Luxton, S., \& Drummond, L. (2000). What is this thing called "ambient advertising"? Australian and New Zeland Marketing Academy Conference (ANZMAC) 2000, (s. 734-738). Gold Coast, Australia.
MacKenzie, S. B., Lutz R. J \& Belch G. E. (1986). The role of attitude toward the ad as a mediator of advertising effectiveness: A test of competing explanations. Journal of Marketing, 23 (2), 130-143.

Maniu, A. I., \& Zaharie, M. M. (2014). Ambient advertising- the contextual influence on message perception. Romanian Journal of Marketing, (2), 45-50.

Maniu, A.-I., \& Zaharie, M.-M. (2014). Advertising creativity - the right balance between surprise, medium and message relevance. Procedia Economics and Finance, (15), 1165-1172.

Maria, A. J., \& Ioan, P. (2013). Schema congruity-A basis for evaluating ambient advertising effectiveness. Annals of Faculty of Economics, 1 (1), 1765-1774.

Mughari, A. M. (2011). Analysis of brand awareness and guerrilla marketing in Iranian SME's. Iranian Journal of Management Studies, 4 (1), 115-129.

Nardalı, S. (2009). Gerilla pazarlaması ve uygulamadaki bazı örnekleri. Yönetim ve Ekonomi, 16 (2), 107-119.

Navratilova, L., \& Milichovsky, F. (2015). Ways of using guerrilla marketing in SME's . Procedia-Social and Behavioral Sciences, (175), 268-274.

Odabaşı, Y., \& Barış, G. (2014). Tüketici Davranışı. İstanbul: MediaCat.

Özdemir, E., \& Tokol, T. (2008). Kadın tüketicilere yönelik pazarlama stratejileri. Anadolu Üniversitesi Sosyal Bilimler Dergisi, 8 (2), 57-80.

Özgül, N. (2008). Bütünleşik pazarlama iletişiminde gerilla pazarlama stratejilerinin kullanımı. Yayınlanmamış Yüksek Lisans Tezi. İzmir: Ege Üniversitesi.

Prevot, A. (2009). The effects of guerrilla marketing on brand equity. The Consortium Journal, 13 (2), 33-40. 
Reyburn, D. (2010). Ambient advertising healthcare media in a new context. Marketing Health Services, $30(1), 8-11$.

Rosengren, S. (2008). Publicity vs. Advertising in a cluttered environment: Effects on attention and brand identification. Journal of Current Issues and Research in Advertising, 30 (2), 27-35.

Rosengren, S., Modig, E., \& Dahlen, M. (2015). The value of ambient communication from a consumer perspective. Journal of Marketing Communication, 21 (1), 20-32.

Saucet, M., \& Cova, B. (2015). The secret lives of unconventional campaigns: Street marketing on the fringe. Journal of Marketing Communication, 21 (1), 65-77.

Shankar, A., \& Horton, B. (1999). Ambient media: Advertising's new media opportunity? International Journal of Advertising, 18 (3), 1-12.

Schiffman, L. G., \& Wisenblit, J. L. (2015). Consumer Behaviour. Essex: Pearson.

Solomon, M. R. (2013). Consumer Behaviour Buying, Having, and Being. Essex: Pearson.

Tam, D. D., \& Khuong, M. N. (2015). The effects of guerrilla marketing on gen y's purchase intention- A study in Ho Chi Minh city, Vietnam . International Journal of Trade, Economics and Finance, 6 (4), 191-198.

Ünal, H. (2013). Gerilla tarz1 pazarlama ve spor. Ankara Üniversitesi Spor Bilimleri Fakültesi Dergisi, 11 (2), 61-71.

Wu, J., Saxena, A., \& Arora, A. (2016). Experience the "ambience": Testing perceptions of ambient advertising innovations between the United States and Indian consumers. International Journal of Emerging Markets, 11 (2), 148-174.
Yoon, H. J. (2013). Understanding schema incongruity as a process in advertising: Review and future recommendations . Journal of Marketing Communications, 19 (5), 360-376.

Zenetti, G., \& Klapper, D. (2016). Advertising effects under consumer heterogeneity: The moderating role of brand experience, advertising recall and attitude. Journal of Retailing, 92, 352-372.

http://www.campaignlive.co.uk/article/53874/mediamedia-choice-ambient-media\# (Erişim Tarihi: 01.06.2016)

http://www.campaignlive.co.uk/article/51034/ ambient-media-ambient-media (Erişim Tarihi:01.06.2016)

http://www.campaignlive.co.uk/article/59016/ambient-media-ambient-trail- (Erişim Tarihi: 01.06.2016)

https://tr.pinterest.com/pin/523121312936348957/ (Erişim Tarihi: 25.06.2016)

https://tr.pinterest.com/pin/84442561734522628/ (Erişim Tarihi: 25.06.2016)

https://tr.pinterest.com/pin/162270392794045420/ (Erişim Tarihi:10.06.2016)

https://www.anadolu.edu.tr/universitemiz/sayilarla-universitemiz/ogrenci-sayilari/2015-2016ogrenci-sayilari/eylul-2015 (Erişim Tarihi: 01.07.2016) 


\section{Ek A. Geleneksel Reklam Örneği}

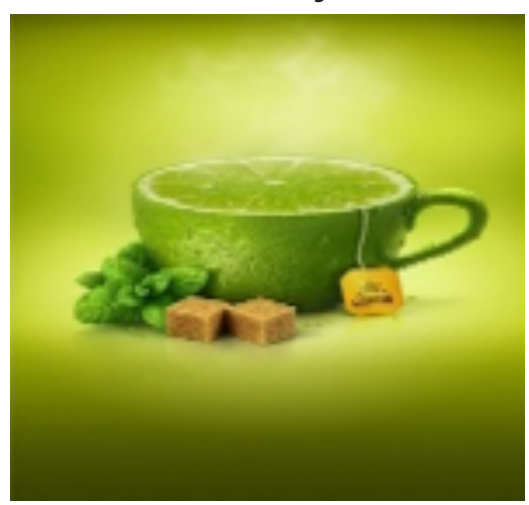

\section{Ek B. Ambient Reklam Örneği}

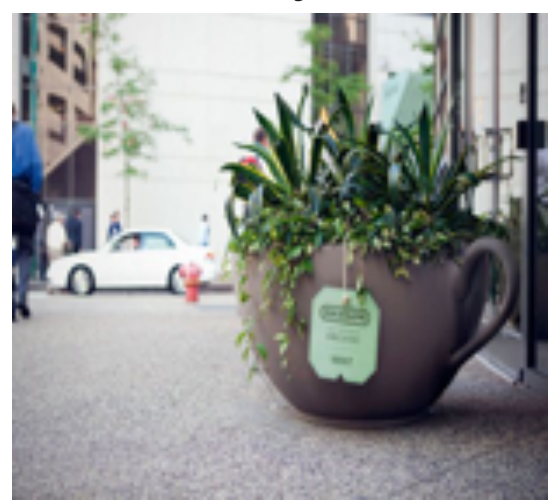

